\title{
MÉDICOS E LOUCOS NO SUL DO BRASIL: UM OLHAR SOBRE O HOSPÍCIO SÃO PEDRO DE PORTO ALEGRE/RS, SEUS INTERNOS E AS PRÁTICAS DE TRATAMENTO DA LOUCURA (1884-1924)
}

\section{Yonissa Marmitt Wadi}

Universidade Estadual do Oeste do Paraná

\begin{abstract}
RESUMO
O Hospício São Pedro foi inaugurado em 29 de junho de 1884, sendo o primeiro hospital psiquiátrico do estado do Rio Grande do Sul e um dos primeiros do Brasil, cuja história a partir deste marco, tornou-se correlata da construção da psiquiatria na então província. Este artigo apresenta uma breve história da instituição até a década de 1920, analisando dados sobre a população de internos. Além disto, reflete-se sobre as práticas médicas de assistência no interior do hospício, nas quais foram conjugados na construção da «cura» dos sujeitos, os preceitos da ciência e os atributos físicos e culturais, bem como as experiências de vida dos internos.
\end{abstract}

PALAVRAS-CHAVE: Loucura. Psiquiatria. Hospital psiquiátrico. Práticas médicas. Experiência.

\section{DOCTORS AND MADMEN IN SOUTH OF BRAZIL: AN OVERVIEW ON THE SAO PEDRO HOSPICE IN THE CITY OF PORTO ALEGRE/RS, ITS PA- TIENTS AND ITS PRACTICES OF MADNESS TREATMENT (1884-1924)}

\begin{abstract}
The São Pedro Hospice was inaugurated on June 29, 1884, and it was the first psychiatric hospital of Rio Grande do Sul State and one of the first of Brazil, whose history was in a turning point, and it became correlated with the construction of the psychiatry then province. This article presents an abbreviation history of the institution until the decade of 1920, it analyzes the data of the internal population. Moreover, it deals with the medical practices of attendance inside the hospice, which were combined with the development of the "cure" of the subjects, the precepts of the science and the physical and cultural attributes, as well as the experiences of the inpatients' life.
\end{abstract}

KEY WORDS: Madness. Psychiatry. Psychiatric hospital. Medical practices. Experience. 


\section{BREVE INTRODUÇÃO}

O Hospício São Pedro de Porto Alegre foi o primeiro hospital de alienados do Rio Grande do Sul e um dos primeiros do Brasil, cuja história a partir do ano de sua inauguração (1884), tornou-se correlata da construção da psiquiatria na então província. A trajetória que culminou em sua fundação foi o resultado de um projeto filantrópico que teve origem na Santa Casa de Misericórdia da cidade - por volta de 1866 - capitaneado pelos dirigentes maiores desta, os provedores. Os médicos foram coadjuvantes no processo histórico que levou à criação do hospício. Criada a instituição, apenas um médico atuava nela respondendo pela direção do serviço sanitário e prestando atendimento a todos os internos. A transformação do hospício em espaço de exercício do saber médico - de uma medicina especial, a psiquiatria - foi um processo lento ${ }^{1}$.

Documentos referentes ao hospital indicam a existência de períodos diferenciados na luta médica pelo domínio do espaço institucional. O primeiro período iniciou-se com a inauguração do hospício e transferência dos primeiros alienados para seu espaço físico em 1884, caracterizando-se como um momento de configuração do discurso psiquiátrico. Em meados da década de 1920, mudanças expressivas no hospício assinalaram uma espécie de 'vitória' dos médicos, ou momento de afirmação de seu saber sobre o espaço institucional ${ }^{2}$.

Entre os anos de 1884 e 1924, os médicos diretores do Hospício São Pedro - em seus relatórios anuais - reivindicavam maior poder sobre a instituição. Acusavam autoridades públicas e a própria sociedade de irresponsabilidade para com o hospital, atribuindo-lhes a culpa por problemas na estrutura, que criavam obstáculos ao bom uso do saber médico, que impossibilitavam um tratamento eficaz e a cura da loucura dos internos. Porém, apesar das queixas dos médicos e através de práticas diversas que visavam, segundo eles, pro-

1 Cf. WADI, Y. (2002a), Palácio para guardar doidos: uma história das lutas pela construção do hospital de alienados e da psiquiatria no Rio Grande do Sul, Porto Alegre, Editora da Universidade / UFRGS. Neste livro discutiu-se a constituição do hospital de alienados e da psiquiatria no estado do Rio Grande do Sul / Brasil, enfatizando-se as lutas travadas, especialmente pelos médicos, para tornar o hospício um lugar de exercício do saber e do poder da psiquiatria nascente. Neste artigo serão retomadas algumas das discussões constantes no referido livro.

2 A partir de meados da década de vinte do século passado, até a década de 1940, parte das reivindicações dos médicos se consolidaram, ou como novas instituições desdobradas da instituição central e que convergiam para esta, como a Colônia Agrícola, o Manicômio Judiciário ou os postos de psicopatas; ou como uma nova legislação, o Regulamento da Assistência a Alienados do Estado do Rio Grande do Sul que reconheceu, através de inúmeras cláusulas, a psiquiatria como o discurso verdadeiro sobre a loucura e os psiquiatras como os legítimos enunciadores deste. Cf. WADI (2002a). 
mover a cura da loucura e restabelecer a saúde (física, mental e moral), certo é que a figura do louco não deixou de ser construída à medida que diferentes indivíduos ingressaram no hospício. Analisando relatórios dos médicos diretores e dos administradores, regulamentos do hospital e prontuários, entre outros documentos, este artigo pretende contribuir para desvelar o movimento ocorrido da fundação do hospital até meados da década de 1920, apresentando a instituição e analisando dados sobre a população de internos. Reflete-se também, a partir da trajetória de uma interna, sobre as práticas médicas de assistência no interior do hospício, nas quais foram conjugados na construção da «cura» dos sujeitos, os preceitos da ciência e os atributos físicos e culturais, bem como as experiências de vida dos internos.

O HOSPÍCIO E OS ALIENISTAS: A CONSTRUÇÃO DO SABER-PODER NA DEFINIÇÃO DE UM ESPAÇO TERAPÊUTICO

Num arrabalde pouco habitado da cidade de Porto Alegre, chamado Partenon, foi inaugurado em 29 de junho de 1884, o Hospício São Pedro. A inauguração do hospício nas cercanias da cidade foi uma das maiores conquistas da filantropia sul-riograndense que desde meados da década de 1860 vinha lutando pela construção de um hospital de alienados separado da Santa Casa de Misericórdia. O primeiro hospital de alienados da província, também um dos primeiros do Brasil, foi inaugurado com pompa e, conforme as palavras do Provedor da Santa Casa — seu diretor geral na época-, era «grande, solidamente construído, amplamente ventilado, colocado na situação a mais recomendada pela ciência, entregue a um diretor distinto», constituindo-se assim num «estabelecimento digno [da] província» ${ }^{3}$.

Porém, transcorrida pouco mais de uma década o hospício já não era visto apenas como uma promessa de tempos melhores para os infelizes alienados, que até sua inauguração eram recolhidos ora aos porões da Santa Casa, ora aos cárceres espalhados pela província. Era já uma realidade. No entanto, às entusiásticas saudações que marcaram sua inauguração, seguiram-se muito cedo uma série de críticas e reivindicações encaminhadas, principalmente, pelos médicos que gradualmente passaram a atuar na instituição. Desde o início do funcionamento do hospício percebeu-se a existência de sérias fissuras na estrutura da instituição modelar da psiquiatria nascente.

3 Relatório da Provedoria da Santa Casa de Misericórdia de Porto Alegre - RPSCM (1884), p. 12. Procedeu-se a atualização ortográfica em todas as citações de documentos. 
Quando o São Pedro foi inaugurado, em 1884, apenas parte do seu projeto inicial fora construído e outra parte encontrava-se em construção ${ }^{4}$. O hospital foi elogiado, desde o projeto, por cumprir as prescrições da psiquiatria quanto à ordem externa, pois sua localização realizava as condições necessárias a uma casa desta ordem, satisfazendo em plenitude as exigências científicas, ou seja, estava «colocado á uma légua mais ou menos distante da cidade, cercado de um lado de esplendida vegetação, de outro lado por lindas colinas, possuindo água em abundancia». Porém, sua estrutura interna, não atendera «aos reclamos da medicina mental». Conforme Carlos Lisboa - primeiro médico diretor da instituição - o eminente alienista Falret já estabelecera que «a construção de um Hospício devia ser antes a realização dos princípios que a medicina mental estabelece, do que a obra de um arquiteto.» Ele, doutor Lisboa, preferia acreditar «que na construção de um Hospício o alienista e o arquiteto devem andar de mãos dadas; — devem obrar de comum acordo: —a construção de um Hospício deve ser obra de ambos» $»^{5}$.

Com a proclamação da República no Brasil, em 1889, o Hospício São Pedro deixou de ser administrado pela Provedoria da Santa Casa e passou a ser custeado pelo Governo do Estado e dirigido por médicos, porém muitos dos problemas existentes desde o início de seu funcionamento, como o relativo ao término da construção do edifício, não haviam sido inteiramente resolvidos até o início da década de 1920. Os médicos que ocuparam a direção do estabelecimento preocuparam-se em seus relatórios anuais e em diferentes documentos enviados à Secretaria do Interior e Exterior ou à Diretoria de Obras Públicas do Estado, em reivindicar a execução do projeto do hospício na integra ou a construção de novos pavilhões para dormitórios, para isolamento de alienados portadores de doenças infecciosas ou contagiosas, para instalação de serviços como farmácia, gabinete hidroterápico e eletroterápico, cozinha, biblioteca e oficinas de trabalho.

Inúmeras vezes, os diretores pediram apenas melhorias no que já existia, pois além do prédio propriamente dito, era preciso dotar o hospício de serviços básicos para que pudesse comportar uma população sempre crescente. Por outro lado, o problema do edifício parcialmente construído, sem infraestrutura básica (em termos de fornecimento de água, esgotos, salas, dormitórios, etc.), trazia consigo o problema da superlotação, o problema da vigilância e da falta de pessoal, além de tornar quase impossível o correto tratamento médico. Como identificaram Machado e seus colaboradores, «Na ação da

4 Godoy, J. (1955), Psiquiatria no Rio Grande do Sul, Porto Alegre, Edição do Autor.

5 Relatório da Diretoria do Hospício São Pedro - RDHSP (1884), p. 4. 
medicina com relação à loucura tudo converge para a implantação deste espaço específico de reclusão que, abrigando as pessoas consideradas doentes mentais, é capaz de recuperá-las pela própria força terapêutica de sua organização» ${ }^{6}$.

Ano a ano, entre outros problemas, os criados pelo crescimento da população asilada foram descritos nos relatórios dos médicos diretores que indicavam suas causas, bem como reivindicavam soluções. Em 1897, o diretor Francisco Dias de Castro - seguindo o pensamento do mestre Esquirol - sugeria que a população asilada aumentava gradativamente em função da própria «evolução sociológica, isto é, sob a influencia das paixões dominantes, que sempre perturbam um povo em suas fases de progresso político ou comercial» ${ }^{7}$.

$\mathrm{O}$ aumento no número de internações chegando à superlotação trazia consigo outros problemas como, por exemplo, o do crescimento de doentes incuráveis que ocupavam o espaço do hospício. A razão do número destes doentes tornar-se cada vez maior no interior da instituição era, nas palavras do Dr. Dias de Castro, fruto do preconceito da sociedade - «que infelizmente reina entre nós, como em toda parte, contra os hospitais em geral e máxime contra os asilos de alienados»-, bem como do desconhecimento quanto ao real benefício que a instituição médica prestava à loucura, pois esta «torna-se rapidamente incurável uma vez perdida a oportunidade para o emprego racional e metódico dos recursos que a psiquiatria dispõe para o seu tratamento» ${ }^{8}$. Algumas motivações do preconceito ficavam claras na medida em que, segundo o diretor, nos hospícios «mais do que nos hospitais comuns», era necessário impor-se «em beneficio dos enfermos, para quem o isolamento é um dos melhores meios de cura, a sua separação prolongada dos entes que lhe são caros». Sendo assim, muitas famílias ou responsáveis só procuravam o hospital «quando o estado mental dos infelizes os tornam de todo incompatíveis com a vida social, e na maior parte dos casos quando a moléstia já não é mais acessível aos meios de tratamento» ${ }^{9}$.

Além disso, para os médicos a superlotação gerava dificuldades maiores de acomodação dos doentes no precário espaço construído do hospício e, mais do que isso, era uma das causas da impossibilidade de proceder a uma classificação científica, base de todo tratamento racional daqueles que se encontravam doentes. Classificação esta, nas palavras do médico, de extrema «importância em um estabelecimento desta ordem, que constitui um dos mais sérios embara-

6 Cf. MACHADO, R. et al. (1978), Danação da norma: medicina social e constituição da psiquiatria no Brasil, Rio de Janeiro, Graal, p. 448.

7 RDHSP (1897), pp. 508-9.

8 RDHSP (1900), p. 70.

9 RDHSP (1900), p. 70. 
ços, acarretando mui graves inconvenientes não só para os doentes que ainda podem recuperar a razão, mas ainda para os próprios incuráveis» ${ }^{10}$.

As soluções cogitadas pelos diretores para o problema da superlotação parecem a princípio contraditórias, pois, se por um lado reivindicavam a internação rápida daqueles que apresentassem sintomas de alienação, por outro requeriam uma seleção dos doentes a serem internados. Em 1902, o médico diretor Tristão Torres afirmava que, em razão da falta de acomodações, deveriam ser admitidos apenas aqueles cuja moléstia constituísse um perigo para si ou para outrem. Porém, segundo ele, o estabelecimento seguia abrindo suas portas a pessoas cujas psicoses lhes permitiriam perfeitamente a permanência em seus domicílios - como lipemaníacos, epilépticos, neurastênicos, débeis - sem outro inconveniente que o de ficarem por um tempo maior privados do tratamento adequado num hospital apropriado ${ }^{11}$.

O hospital abria suas portas também a indivíduos que tinham cometido crimes e eram suspeitos de tê-lo feito sob o efeito de um 'estado de loucura', ou então, que haviam enlouquecido nas prisões após serem condenados. Também esta postura gerará imensa polêmica alguns anos depois, na reivindicação da criação de um estabelecimento especial para tal classe de alienados.

Por volta de 1900, o diretor Dias de Castro tentara estabelecer uma política de limitação das internações até que a população do hospício estivesse de acordo com seus alojamentos, justificando ser a única maneira de evitar a continuação do acúmulo de doentes com o seu cortejo de inconvenientes desastrosos. Afirmava que vacilara durante muito tempo em fechar as portas do hospício, pois, este se achava em melhores condições de, pelo menos, «asilar os infelizes privados da razão, do que as prisões e os outros hospitais do Estado». Advertia, no entanto, que não se podia esquecer «que é muito mais humanitário curar poucos dentre alguns do que asilar muitos e não curar um só» ${ }^{12}$.

10 RDHSP (1899), p. 6.

11 RDHSP (1902), p. 233. Para os alienistas deste período - final do século XIX, início do XX - a loucura já era considerada essencialmente uma doença especial — doença mental- e neste sentido, qualquer separação em gêneros ou espécies deveria obedecer a uma observação rigorosa da sintomatologia e basear-se em critérios nosológicos rigorosos e objetivos. A utilização de tais critérios não constituia uma regra no Hospício São Pedro, pois segundo os médicos-diretores haveria a impossibilidade concreta para seu estabelecimento. Para um melhor entendimento da classificação das 'doenças mentais' neste período, cf.: FOUCAult, M. (1989), História da loucura na idade clássica, São Paulo, Perspectiva; Foucault, M. (1975), Doença mental e psicologia, Rio de Janeiro, Tempo Brasileiro; PessotTI, I. (1994), A loucura e as épocas, Rio de Janeiro, Ed. 34.

12 RDHSP (1901), p. 158. 
Porém, as tentativas de estabelecer uma política restritiva às internações, não se concretizaram — segundo os médicos - em função de ingerências de autoridades públicas que detinham, além do direito regulamentar de solicitar o internamento de supostos loucos, também poder suficiente para podar iniciativas do saber médico. Em trecho do relatório de 1902, o diretor afirma ter informado ao Chefe de Polícia - quando este solicitou vagas para doentesque o Hospício estava com a sua lotação já excedida e que por isso não podia aceitar mais enfermos. Porém, que fora «obrigado a infringir o elementar preceito higiênico de não permitir o acúmulo nosocomial, porque as requisições da Chefatura de Policia, vinham então de ordem do Exmo. Sr. Desembargador Presidente do Estado» ${ }^{13}$.

A ingerência direta das autoridades públicas modificando decisões dos médicos, assim como sua ineficiência em cumprir com os encargos mínimos para manter o bom andamento do hospício, constituiam limites para a configuração deste como espaço terapêutico, bem como para o exercício do saber e o estabelecimento do poder médico sobre a instituição.

A superlotação do hospício colocava outro problema real a ser solucionado pelos diretores: a vigilância sobre os alienados. O crescente número de doentes, em acomodações inadequadas, tornava impossível manter a vigilância, princípio fundamental da prática psiquiátrica, permitindo que certos acontecimentos - como assassinatos ou fugas - perturbassem a manutenção da boa ordem. Para sanar o problema da vigilância, diziam os diretores do São Pedro, era imprescindível que houvesse médicos e auxiliares (enfermeiros e guardas), em maior número, com melhores condições de trabalho e melhores salários. Mas, além disto, os médicos deveriam ter maior poder sobre a instituição.

Quanto à primeira questão, as queixas e reivindicações mantiveram-se num tom semelhante durante todo o período. Para o Dr. Dias de Castro, era praticamente impossível achar auxiliares para tratar com alienados, visto serem os salários pagos àqueles inferiores ao de qualquer jornaleiro. Neste sentido, urgia oferecer-lhes remuneração proporcional à tarefa imposta, bem como aumentar o número de tais empregados, pois, a experiência vinha demonstrando - segundo este- que os indivíduos afetados de moléstias mentais reclamavam tratamento individual. Para que o médico pudesse colocar «em pratica a análise psicológica quotidiana e exame físico, exigidos pelo diagnóstico e tratamento das formas tão variadas da loucura», era indispensável ter no mínimo um empregado para dez doentes ${ }^{14}$.

13 RDHSP (1902), p. 233.

14 RDHSP (1896), pp. 347-8. 
A reivindicação de maior poder para os médicos, como solução para o problema da vigilância, estava inserida em uma problemática bastante complexa, ou seja, a luta por poder no sentido de estabelecimento, aceitação e legitimação da psiquiatria. Nesta luta, as práticas médicas deviam ser articuladas com o intuito de resolver os problemas colocados pelo cotidiano institucional. Reconhecer e buscar soluções para o problema da vigilância dos alienados, bem como para outros que surgiam diariamente no hospício, significava conquistar espaço num palco onde vários atores colocavam-se como principais. Neste sentido, alienistas - formados mais pela prática cotidiana do que por ensinamentos de uma ciência- precisaram se construir como os legítimos enunciadores da verdade da loucura. Eles o fizeram através de estratégias diversas como apontar os diferentes problemas que não permitiam que o hospício cumprisse suas reais atribuições ou desconstruir outros discursos que se sobrepunham ao seu, como o das autoridades públicas.

Um trecho do relatório da diretoria, de 1897, esboçou com clareza aquilo que, na percepção dos alienistas, deveria ser de fato reconhecido por toda a sociedade, mormente pelas autoridades públicas estaduais. Citando Esquirol, o médico Dias de Castro, afirmou: «O médico é, de algum modo, o princípio da vida de um hospício de alienados; a ele compete dirigir todas as ações, porque ele deve ser o regulador de todos os pensamentos ${ }^{15}$. Para o alienista foi o reconhecimento da verdade contida nesta asserção e, a conseqüente compreensão das vantagens do estabelecimento de um perfeito acordo entre a direção moral e a direção material dos asilos de alienados, que fizera com que governos, de muitos países, entregassem tais direções a um profissional que acumulava funções médica e administrativa. Da mesma forma, segundo o alienista, já estava «exuberantemente demonstrado pela experiência de longos anos» que a primeira condição para que o hospício correspondesse ao seu destino, era que ele só tivesse um chefe, ao quem todos obedecessem, pois, «a separação dos serviços produz sempre uma completa desarmonia de vistas, trazendo como corolários sérios inconvenientes para o fim especial desses estabelecimentos, que é a cura ou pelo menos o bem estar dos infelizes que recorrem a seu amparo» ${ }^{16}$.

O reconhecimento da verdade, a compreensão das vantagens e a demonstração pela experiência, dos princípios contidos no preceito de Esquirol eram as provas reais de que deveriam ser os médicos os condutores dos processos (terapêutico e administrativo) que determinavam o que era doença, a interdição,

15 RDHSP (1897), p. 510.

16 RDHSP (1897), p. 510. 
o tratamento e a cura. Pois era claro, segundo o diretor, que as aptidões especiais e os esforços empregados pelos médicos para garantir a cura ou pelo menos a atenuação das desordens psíquicas dos internos, contrastava com a atuação dos administradores, em geral pessoas carentes de «cultura moral e intelectual precisa para tão melindrosa função». Assim, longe de auxiliar os facultativos no desempenho das delicadas tarefas que aqueles cabiam, só cuidavam de garantir a prosperidade material do estabelecimento, embora em desacordo com os nobres fins a que era destinado ${ }^{17}$.

Mesmo que, o primeiro governo republicano do Rio Grande do Sul, tivesse confiado a um médico a direção de todos os serviços a cargo do hospício, não estavam sendo atendidas, segundo os médicos, muitas das reivindicações essenciais ao bom exercício da função, tornando nada mais do que uma quimera a idéia de curar a doença mental. O Regulamento de 1892, por exemplo, estabelecia que o diretor residisse junto ao estabelecimento, atribuição não cumprida, pois o governo não havia construído uma casa para este. Para o diretor na época, Dias de Castro, ao não residir no estabelecimento era impossível que o médico fiscalizasse convenientemente os diversos serviços a seu cargo, pois não possuía auxiliares com o necessário zelo e aptidão. Acreditava o médico que «Para educar convenientemente o pessoal que serve sob suas ordens no exercício de funções tão variadas, e que reclamam uma atividade infatigável, é necessário que a toda hora, quer de dia, quer de noite, ele possa tê-lo debaixo de sua vigilância enérgica e inteligente» ${ }^{18}$.

A construção da positividade do sujeito médico passava, como se pode perceber através do fragmento acima, pela desconstrução de outros sujeitos sociais envolvidos no mesmo campo discursivo e pela reafirmação constante da competência médica para assumir inclusive, o ônus da gestão da loucura.

No que se referia à questão do tratamento médico específico, aos cuidados físicos, higiênicos e morais, o discurso médico também se manteve o mesmo, no período de quase quarenta anos decorridos da fundação até a década de 1920. Os problemas arrolados sucediam-se numa cadeia ininterrupta de problemas geradores de outros: maior número de admissões de enfermos (princi-

17 RDHSP (1897), pp. 510-11.

18 RDHSP (1897), p. 511. A crença do diretor Dias de Castro a respeito de tais benefícios era tanta que ele acabou por construir sua residência em frente ao hospício, ao que parece sem nenhum auxílio do governo do Estado. Cf. SouZA, D. (1943), Notícia histórica sobre as origens da assistência a psicopatas no Rio Grande do Sul e sua evolução. Em FrANCO, A., RAMOS, S.M. (org.), Panteão médico riograndense: síntese histórica e cultural, São Paulo, Ramos e Franco editores, p. 80. 
palmente incuráveis) do que de saídas ou óbitos, aglomeração de alienados nas salas e dormitórios, má alimentação, maior número de doenças do aparelho digestivo e de doenças infecciosas, falta de aparelhos, máquinas e instrumentos para a realização do tratamento físico, poucas oficinas para a realização do tratamento moral. Todos estes problemas atuando uns sobre os outros dificultavam ou até mesmo impediam, em determinados momentos, qualquer tratamento. A resolução dos problemas relativos à questão do tratamento não rompeu a regra estabelecida na resolução dos demais, ou seja, soluções precárias e provisórias na maioria das vezes: o uso da hidroterapia - com a qual colheram bons resultados no tratamento das psicoses agudas e crônicas- ou dos meios farmacêuticos que, para os médicos, nesta parte especial da patologia satisfaziam apenas às indicações sintomáticas. Porém, creditavam a hidroterapia e aos recursos de ordem moral, disponíveis em pequena escala e escrupulosamente aproveitados, os casos de cura e as altas em melhores condições observadas na estatística do hospício ${ }^{19}$.

Em 1908, o Dr. Ferreira, de forma lacônica, sintetizou a realidade dos primeiros quarenta anos de funcionamento do hospital São Pedro, ou seja, nenhuma modificação substancial realizada, ainda que muitas fossem imprescindíveis e urgentes, «como a regularização dos internamentos, os subsídios das Intendências, o aumento de pessoal e a construção de abrigos para atender convenientemente sobre o ponto de vista psíquico e somático aos insanos [do] Estado» ${ }^{20}$.

Outros exemplos poderiam ser extraídos dos relatórios do período, porém nenhum deles ultrapassa as demarcações esboçadas pelos diretores, num tom monocórdio e ritmado: reivindicações diversas e a constatação de pequenas melhorias na situação dos internos acompanhando as poucas melhorias no tratamento dispensado. As raras mudanças no São Pedro, conquistadas ao longo de anos, no sentido de transformá-lo em espaço de exercício da psiquiatria em prol dos alienados atestavam, segundo um dos médicos-diretores, «os constantes desvelos dispensados pelo pessoal do nosso estabelecimento aos infelizes confiados à sua guarda» ${ }^{21}$.

19 RDHSP (1895), p. 227.

20 RDHSP (1908), p. 204.

21 RDHSP (1900), p. 570. 


\section{Os LOUCOS Do HosPÍcIO SÃo PEDRO}

Da transferência dos primeiros alienados — 24 homens e 17 mulheres — da Santa Casa de Misericórdia e da Cadeia Pública de Porto Alegre para as dependências do São Pedro, em 1884, até o início da década de 1920, os homens sempre constituíram a maioria dos internos. Sua participação no total geral da população interna girou entre 50 e $60 \%$ e o de mulheres ficou entre 40 e $50 \%$ no mesmo período 22 .

A partir de 1918 até o ano de 1922, o número de mulheres internas gradativamente superou o de homens, numa média de 53\% para 47\% ${ }^{23}$. Apesar da ausência de dados sobre o crescimento da população interna para os anos de 1923 a 1926, este parece ter se mantido constante, pois os dados de 1927 indicam crescimento superior da população feminina: $53 \%$ do total de internos no Hospício São Pedro eram mulheres, enquanto 47\% eram homens.

Da inauguração até o ano de 1916, o número de admissões de homens foi sempre superior ao de mulheres, numa relação de $61 \%$ para $39 \%$, o que se refletiu nos números absolutos, ou seja, nos totais apurados a cada ano. Alterações nestes números podem ser verificadas a partir de 1917, quando o número de mulheres superou o de homens, porém sem uma modificação sensível do padrão de internações.

Até por volta de 1923, a admissão de mulheres sempre ficou abaixo da de homens, porém a população feminina do hospício logo superou a masculina, o que pode ser explicado por uma operação matemática simples: o número de internos existente, somadas as entradas e diminuídas as saídas. O resultado é exato: se as mulheres entraram menos, mas se transformaram no maior contingente de internos, é porque também saíram menos. Diversos autores indicam que no decorrer do século $\mathrm{XX}$ as mulheres passaram a ocupar gradativamente a maioria dos leitos dos hospitais psiquiátricos, constituindo-se

22 Os percentuais foram construídos com base em dados do mês de dezembro de cada ano, constantes em quadros que consideram o $\mathrm{n}^{\circ}$. de internos existentes, as entradas durante $\mathrm{o}$ ano, as saídas, os falecimentos e os existentes ao final do ano. Apenas para o ano de 1894 os dados referem-se ao mês de junho, mês do relatório anual de funcionamento do HSP. Estes quadros constam nos Relatórios da Direção do Hospício São Pedro (1884 a 1921) e nos Anuários Estatísticos do Rio Grande do Sul (1920, 1921, 1922 e 1927) e foram usados para construir as estatísticas citadas.

23 O ano de 1919 constitui uma exceção neste quadro, pois naquele ano os homens eram $51 \%$ e as mulheres, $49 \%$ dos internos do Hospício São Pedro. 
também na maioria das pacientes de clínicas particulares, o que não foi diferente no hospital São Pedro ${ }^{24}$.

Nas interpretações médicas do início do século XX, a loucura nos homens se manifestava fundamentalmente na quebra dos papéis sociais desempenhados no espaço público, o de trabalhador ou cidadão: ausência de razão, mau uso da liberdade, privação dos sentidos, comportamentos estranhos ou antisociais. Nas mulheres, ao contrário, a loucura se manifestava preferencialmente na esfera privada, dominada pelas questões do corpo, da sexualidade e da família, aparecendo como mais transgressiva do que nos homens ${ }^{25}$.

Os dados relativos aos motivos das altas de homens e mulheres no São Pedro são esclarecedores desta percepção. Se a loucura está inscrita no corpo feminino, sujeita aos fluxos e refluxos deste corpo, que são constantes, ininterruptos e permanentes, pelo menos até a menopausa - momento em que o corpo feminino reencontraria o equilíbrio físico e psíquico perdido com a menstruação- e, se os lugares das mulheres na sociedade são mais restritos do que os dos homens, parece evidente que o número de mulheres «curadas» seja sempre inferior ao de homens nas mesmas condições.

Isto fica visível em exemplos extraídos de relatórios. No ano de 1894, observa-se que saíram como «curados», $5 \%$ dos homens e 3\% das mulheres; em 1900 , foram considerados «curados», $8 \%$ dos homens e $4 \%$ das mulheres internas; já em 1914, tiveram alta como «curados», 9\% dos homens e apenas $3 \%$ do total de mulheres internas. No entanto, quando a alta é «a pedido», «provisória», «a requisição de interessados» ou «para assistência em domicílio» - rubricas que necessariamente envolvem a participação dos familiares, tutores, curadores, no acompanhamento dos loucos fora do hospício-, o número de mulheres que saem é igual ou maior ao de homens, superando por vezes os números indicativos de cura para estas. Pode-se citar como exemplo, o que ocorreu no ano de 1900 quando $1 \%$ dos homens e 3\% das mulheres

24 Para autoras como Chesler, Showalter, Gilbert e Gubar e Garcia este é o resultado da conjugação de dois fatores: historicamente a loucura é considerada uma enfermidade feminina e as mulheres vivem situações reais de opressão como esposas, filhas, irmãs e amantes malcompreendidas pela psiquiatria. CHESLER, P. (1989), Women and madness, New York, Harvest Books; SHOWALTER, E. (1985), The female maladie. Women, madness, an english culture, 18301980, London, Penguin Books; Gilbert, S., Gubar, S. (1979), The madwoman in the Attic, New Haven, Yale U.P.; GILBERT, S., GUBAR, S. (1980), No man's land. The place of the women writer in the twentieth century, New Haven, Yale U.P.; GarCiA, C.C. (1995), Ovelhas na névoa: um estudo sobre as mulheres e a loucura, Rio de Janeiro, Record, Rosa dos Tempos.

25 CunHA, M.C.P. (1989), Loucura, gênero feminino: as mulheres do Juquery, na São Paulo do início do século XX, Revista Brasileira de História, 9 (18), 121-144. 
internas tiveram alta «a pedido»; e no ano de 1907, quando saíram do hospício com alta «provisória», $2 \%$ dos homens e $5 \%$ das mulheres. Considerandose estes dados e utilizando-se a argumentação de Chesler, pode-se dizer que, se há uma «margem mais estreita em relação aos erros concedida às mulheres» —o que as leva com maior facilidade ao internamento cometido qualquer deslize social — há, por outro lado, uma maior tolerância, após uma primeira internação, para com certas mulheres que garante o retorno as suas casas, «pois delas depende o trabalho doméstico» ${ }^{26}$.

Limitações legais para altas concedidas para «assistência em domicílio», «provisórias» ou «a pedido», previstas nos regulamentos talvez tenham contribuído para esta maior 'tolerância' com as mulheres. Havia a necessidade de formalização de um compromisso, por parte de quem solicitou a saída para assistência, com os cuidados necessários ao bem-estar do doente e estes cuidados deveriam ser preferencialmente ministrados por pessoal médico do próprio hospital. Assim, para que o doente voltasse a ser internado no hospital, bastaria que os responsáveis legais percebendo 'novos sinais de crise' ou 'recaídas', solicitassem nova entrada. Não havia nestes casos, a necessidade de cumprimento dos trâmites legais previstos nos regulamentos, como a obtenção de atestados de peritos que tivessem examinado o doente anteriormente e constatado a necessidade da internação. Esta é uma cláusula interessante pela facilidade dada aos interessados de livrarem-se de seus pesos, especialmente os afetivos. Talvez tal cláusula tenha possibilitado uma freqüência maior de re-internações confirmando, no caso das mulheres, sua submissão à autoridade de seus responsáveis. Para tal submissão contribuía também outra cláusula vigente nos diferentes regulamentos do período: as mulheres, quando não tinham constatada sua loucura em momentos de admissão provisória ou quando a alta fora dada, só poderiam sair do hospício se fossem entregues à pessoa responsável pela internação ${ }^{27}$.

Separados de outros motivos de saída, que foram agregados, os «falecimentos» representam o maior número destas nas estatísticas do hospício. Homens e mulheres que foram internados tiveram na morte, na maioria das vezes, a única chance de sair do "cemitério dos vivos» ${ }^{28}$. Algumas pessoas remetidas ao hospital já doentes, e não (ou somente) da mente como diziam

26 Apud GaRCIA (1995), p. 15.

27 Esta cláusula vale também para os menores de idade e consta nos regulamentos do Hospício São Pedro de 1884, 1892, 1903 e 1925.

28 Assim denominava o hospício o escritor Lima Barreto. Cf. BARRETO, Lima (1956), $O$ Cemitério dos vivos: memórias, São Paulo, Brasiliense. 
os alienistas, mas sim (ou também) do corpo, com doenças somáticas, morreram em suas dependências. Outros, por não aceitarem a internação ou não suportarem a vida no hospício —ou apenas a vida — cometeram suicídio. Há ainda os que perderam a vida por causas outras, que a memória do hospício não registrou e que o olhar contemporâneo não alcança.

Entre as mulheres, na maioria das estatísticas a que se teve acesso, «falecimento» foi a causa maior de saída do hospício no período destacado. Consideradas as outras possibilidades de sair do hospício - «curado», "para assistência em domicílio», «em melhores condições», «fuga»- a morte apresentou-se, quase sempre, como a maior (ou única) possibilidade de saída. Os índices relativos aos anos de 1894 e 1990 são esclarecedores. Em 1894, considerado o total de mulheres internas, o índice de «falecimentos» foi de $16 \%$, contra $7 \%$ de outros motivos de saídas. No ano de $1900,14 \%$ do total de internas saiu do hospício por «falecimento» e $12 \%$ por outras causas diversas. Já o decênio 1884-1894 contabilizou um índice de 42\% do total de internas que faleceram, enquanto apenas $32 \%$ saíram por outros motivos. Também entre os homens, o «falecimento» teve índice expressivo como motivo de alta. No decênio 1884-1894, para citar um único exemplo, 41\% dos homens internos tiveram alta por motivos diversos e outros $36 \%$ por «falecimento».

Estes dados colocam em evidência algumas das características do São Pedro que, como os demais hospitais de alienados deste período histórico, funcionaram muito mais como depósitos de despossuídos de todas as espécies do que lugar de terapêutica, de cura de uma doença especial ${ }^{29}$. Sobre as precárias condições do edifício, os parcos recursos terapêuticos, a falta de verbas, para o melhor tratamento dos doentes e para que as estatísticas fossem mais favoráveis, os médicos diretores do hospício se manifestaram continuamente em todo o período considerado, como se pôde observar. Porém, nem por isso, indivíduos variados cessaram de ser recolhidos ao hospital —e isto também foi justificado pelos médicos-, deixando de oferecer 'perigo' a si mesmos, às famílias e à sociedade. Pessoas internas no hospício deixaram, muitas vezes, em contrapartida, a própria vida — duplamente, enquanto experiência cotidiana ou como experiência biológica - para trás. Foi muitas vezes a morte que encontraram na instituição e não a cura tão propalada pela psiquiatria.

29 Sobre as condições dos hospitais de alienados no Brasil à época de sua formação, ver: CunHa, M.C.P. (1986), O espelho do mundo: Juquery, a história de um asilo, Rio de Janeiro, Paz e Terra; Engel, M.G. (1995), A loucura na cidade do Rio de Janeiro: idéias e vivências (1830-1930), Tese (Doutorado em História)—Programa de Pós-Graduação em História, Universidade Estadual de Campinas; WADI (2002a). 
Uma morte que podia ser redenção para muitos, frente a uma cura nunca, ou quase nunca, ou sob duras condições, atingida por determinados sujeitos sociais, especialmente aqueles marcados, no discurso generalizante da psiquiatria, com os rótulos mais perigosos construídos a partir de parâmetros de gênero, de classe, de raça, de etnia, de geração, entre outros.

O hospício como espelho do mundo, afirma Cunha ${ }^{30}$, era também em termos de composição étnica um espaço dos brancos, o que se pode comprovar pelas estatísticas quanto à cor dos internos do São Pedro. Considerando dados constantes em alguns relatórios dos anos 1899 a 1921, obteve-se uma média de $72 \%$ do total de internos de cor «branca», $11 \%$ de cor «preta», $11 \%$ de cor «parda» e $6 \%$ de cor «indiática» ${ }^{31}$. É importante observar que a distribuição por cor dos internos do São Pedro era semelhante à distribuição da população por cor no Estado, especialmente quanto à majoritária proporção de «brancos» nesta. Conforme o Censo de $1890^{32}$ havia a presença de $70 \%$ de indivíduos de cor «branca», 9\% de cor «preta» e 21\% de cor «parda» no Estado ${ }^{33}$. Não há, porém, dados sobre a relação cor / sexo nos censos do Rio Grande do Sul, como há nos relatórios do hospital São Pedro. Tomando-se os números do relatório de 1899 , como exemplo, verificou-se que $77 \%$ do total de homens e $59 \%$ das mulheres internas eram de cor «branca'; $10 \%$ dos homens e $16 \%$ das mulheres eram de cor «preta»; $13 \%$ dos homens e $24 \%$ das mulheres eram de cor «parda».

Por outro lado, os dados sobre a composição por cor da população do hospício, demonstram que o número de mulheres «pretas» e «pardas», sempre superou o de homens, enquanto o de mulheres «brancas» sempre ficou abaixo, no período. Em 1896, por exemplo, enquanto o percentual de internos de cor «branca», distribuía-se em $68 \%$ de homens e $38 \%$ de mulheres; entre os internos de cor «preta», a distribuição era de $49 \%$ de homens para $51 \%$ de mulheres e entre os de cor «parda», $46 \%$ de homens e $54 \%$ de mulheres. Já em 1913, estas diferenças percentuais se acentuam: enquanto entre os internos de cor «branca», 55\% são homens e 45\% são mulheres; entre os de cor «pre-

30 CunHA (1986), p. 124.

31 As variáveis estão assim nominadas nos relatórios de 1899, 1907, 1913 e 1921.

32 O censo de 1890 foi o único censo realizado no período estudado a trazer dados sobre tal variável. «Censo Estatístico do Rio Grande do Sul, 1890». Em FEE - Fundação de Economia e Estatística (1981), De província de São Pedro a Estado do Rio Grande do Sul. Censos do RS: 1803-1950, Porto Alegre, FEE.

33 A cor «parda», provavelmente incluiu os chamados «indiáticos», pois não há menção a esta variável. 
ta», apenas $43 \%$ são homens e $57 \%$ mulheres, distribuição quase igual a que ocorria entre os indivíduos considerados de cor «parda», 44\% de homens e $56 \%$ de mulheres.

Os dados obtidos nos relatórios do São Pedro confirmam as afirmações de Cunha, quanto à posição absolutamente inferior das mulheres «pretas» e «pardas» na escala de internamento manicomial, pois «são vistas e tratadas pela medicina alienista como portadoras de uma dupla inferioridade que as torna mais próximas da natureza que da condição humana» ${ }^{34}$. $\mathrm{O}$ índice de saídas por falecimentos é bastante alto entre internos de todas as cores, no hospício de Porto Alegre, como se viu. Porém, quando se trata de mulheres «pretas» e «pardas», estes são nitidamente superiores aos encontrados para homens e mulheres «brancos» e homens «pretos» ou «pardos». Considerando-se todo o período circunscrito, verificou-se que $44 \%$ das mulheres de cor «parda» e 46\% das mulheres de cor «preta» que saíram do São Pedro, o fizeram em razão de falecimento. A situação de dupla inferioridade (sexo/cor) levou tais mulheres, quase inevitavelmente, a um destino trágico — não bastasse a própria tragédia do internamento-, a morte.

Em relação a nacionalidade dos internos observou-se no período, o registro de uma maioria absoluta de brasileiros, ou seja, em torno de $79 \%$ do total. A segunda nacionalidade mais representada foi a italiana, seguida por alemães e portugueses. Em 1908, por exemplo, a distribuição por nacionalidade no Hospício São Pedro estava assim composta: num total de 573 internos, $76,09 \%$ eram brasileiros; $12,39 \%$ italianos; 2,26 alemães; $1,39 \%$ portugueses; $0,34 \%$ franceses e $7,5 \%$ de diversas nacionalidades, predominando os poloneses e russos.

O estado civil predominante entre os internos dos dois sexos, em todo o período, era «solteiro», girando entre $51 \%$ e $68 \%$. Cerca de $25 \%$ dos internos era «casado» e $5 \%$ «viúvo». Um dado interessante é que, entre os «solteiros», o percentual de homens é sempre maior do que o de mulheres, enquanto entre «casados»e «viúvos», este percentual é sempre menor do que o de mulheres.

As faixas etárias de maior presença de internos de ambos os sexos eram as «de 21 a 30 anos» e «de 31 a 40 anos» observando-se que, entre $23 \%$ e $31 \%$ dos internos, em todo o período, pertenciam a estas faixas etárias. Porém, consideradas as mulheres separadamente, há uma representação grande da faixa etária «de 41 a 50 anos», situando-se nesta de $18 \%$ a $27 \%$ das internas.

34 CUNHA (1986), p. 124. 
MÉDICOS E LOUCOS: UM OLHAR SOBRE AS PRÁTICAS TERAPÊUTICAS A PARTIR DA TRAJETÓRIA DE UMA INTERNA

Limitados instrumentos terapêuticos decorrentes, segundo os médicos, do não reconhecimento das necessidades reais para o bom funcionamento do maior de todos eles - o próprio hospício - não impediram, porém, que os alienistas identificassem a «loucura» de cada interno, que buscassem a «cura» desta e o restabelecimento da saúde (física, mental e moral) de cada um, fím preconizado nos regulamentos do São Pedro. A despeito dos limites objetivos postos ao exercício rotineiro de assistir e tratar os doentes - baseado nas elaborações teóricas de uma ciência em construção e alimentado pelas experiências cotidianas-, este não deixou de ser realizado, ainda que existisse uma enorme distância entre o ideal e o real. Mais do que os preceitos e os recursos da ciência psiquiátrica, parece ter contribuído para a construção da loucura de cada interno - e assim do seu destino no labiríntico hospício-, os atributos físicos e culturais, bem como as experiências de vida que os constituíram como sujeitos.

A visualização desta intrincada relação no Hospício São Pedro só se torna possível através da conjugação e análise de diversos documentos, especialmente os relatórios dos médicos-diretores - com suas elucubrações sobre as necessidades, o ideal e a realidade do hospital no que diz respeito ao tratamento médico- e os prontuários com seus anexos ${ }^{35}$. Ainda que, na maioria das vezes em anotações telegráficas, são nestes últimos documentos que encontramos as histórias de sujeitos diversos unidos pela compreensão médica de 'certa' loucura que os acometia. Para discutir tal relação se tomará como exemplo a trajetória de uma mulher interna no Hospício São Pedro entre os anos de 1909 e $1911^{36}$.

35 O termo prontuário, de 1884 até meados da década de 1920, referia-se ao conjunto dos documentos acumulados na trajetória de um paciente dentro do hospital. O prontuário era composto por uma papeleta, que deveria conter os dados de identificação do interno, informações médicas sobre o dia-a-dia deste na instituição e a anotação do diagnóstico; e uma série de anexos, como atestado médico justificando pedido de internação; requisição (de autoridades públicas, como o Chefe de Polícia, ou o Secretario do Interior ou Exterior) ou requerimentos (do ascendente ou descendente; de um dos cônjuges; do tutor ou curador; do chefe da corporação religiosa ou de beneficência) solicitando internação; exames somáticos; atestado de admissão definitiva e, em raros casos, bilhetes ou cartas, dos próprios pacientes ou de procuradores, tutores ou familiares. Poucas das informações e dos anexos exigidos pelos regulamentos do hospício, de fato, se faziam presentes nos prontuários desta época.

36 Cf. WADI, Y. (2002b), Louca pela vida: a história de Pierina, São Paulo, Programa de 
Em 05 de julho de 1909, adentrou os portões do hospício, Pierina Cechini, com 28 anos de idade, de "cor branca», casada, procedente da cidade de Garibaldi e de profissão «serviço doméstico/colona». Pierina fora encaminhada pela Chefatura de Polícia da capital, através de atestado dos médicos legistas, «a fim de ser convenientemente observada», pois cerca de três meses antes cometera uma homicídio, afogando sua filha pequena numa tina no porão da casa em que viviam. O prontuário de Pierina, como o de inúmeros outros internos da época, foi precariamente preenchido. Além dos dados de identificação, na papeleta constavam apenas os itens «diagnóstico» (elaborado quando da admissão permanente) e «observação» (relativa à saída do hospício). Não há nesta nenhum registro quanto ao acompanhamento feito no dia-a-dia, quanto ao tratamento que lhe foi prescrito ou quanto a realização de exames somáticos ${ }^{37}$.

O prontuário de Pierina fornece poucas pistas para o desvelamento da realidade que viveu dentro do hospício, especialmente quanto ao 'tratamento' indicado para certo diagnóstico e a situação particular de sua internação, ou seja, a pedido da justiça. Entretanto, às informações ínfimas contidas naquele sobrepôs-se outro documento: o relatório pericial redigido pelos médicos legistas da Chefatura de Polícia. Este contém informações, segundo os legistas, coligidas a partir de testemunhos (informantes da cidade de origem, inclusive o juiz e familiares da denunciada), das «palestras» que tiveram com Pierina, das cartas que a paciente escreveu quando internada, de conversas com os médicos do hospício ${ }^{38}$. A conjugação destes documentos permitiu a visualização, clara por vezes, em outras através da imaginação histórica, das terapêuticas aplicadas aos internos.

Em primeiro lugar é interessante frisar que a despeito de não existirem observações registradas pelo médico do hospício no prontuário de Pierina -0 que necessariamente não significa que elas não foram feitas-, o diagnóstico dado a ela e registrado coincidia com o elaborado pelos peritos da Chefatura de Polícia. O diagnóstico do alienista do hospício dizia ter Pierina, «Depressão melancólica, com idéias delirantes místicas associadas à perversão

\footnotetext{
Pós-Graduação em História, Pontifícia Universidade Católica de São Paulo. Na referida tese, as relações entre indivíduo, sociedade, sistema judiciário e saber médico psiquiátrico, no Rio Grande do Sul do início do século XX foram configuradas para que pudessem se tornar visíveis as experiências de uma mulher tida como 'louca'. Aspectos da trajetória desta mulher serão retomados neste artigo.

37 HOSPÍCIO SÃO PEDRO (1909). Prontuário n. 38.120 - P. C., APRS (Cx. 06).

38 «Relatório médico-legal dos Drs. João Pitta Pinheiro e Antonio Carlos Penafiel» (1911). Em JUIZO DISTRICTAL DO CIVEL E DO CRIME DO MUNICÍPIO DE GARIBALDI (1909), Processo-crime n. 1009 - P. C., APRS (maço 30 - est. 29).
} 
dos sentimentos afetivos», definido enfim, como «Psicopatia constitucional» ${ }^{39}$. Na versão dos legistas Pierina tinha «estigmas de ordem depressiva, histero-neurastênicos», associados aos «estigmas peculiares à degeneração inferior». Características estas que revelavam aqueles cuja ascendência fora marcada pelos estigmas da raça, da etnia, do sexo ou das 'doenças', como o alcoolismo ou a loucura. Dentre estes estavam os «loucos morais», como Pierina, ou seja, aqueles cujos sentimentos afetivos - tendo como paradigma o amor dos pais pelos filhos- encontravam-se pervertidos ${ }^{40}$.

Os detalhes fornecidos pelos legistas a respeito da terapêutica aplicada a Pierina, contrastadas com as informações contidas nos relatórios dos médicos diretores, permitem uma aproximação com as práticas cotidianas a que eram submetidos os internos do São Pedro, a guisa de tratamento. Segundo os legistas, seu tratamento teve como base a «psicoterapia» ou «tratamento moral», aliado a «melhores cuidados higiênicos», «mudança de ar e de alimentação» e ao próprio «isolamento hospitalar». Este conjunto resultara numa 'terapêutica' que lhe propiciara repouso, aproveitamento físico, engorda e a recuperação da afetividade pelo remorso do crime e a saudade da família ${ }^{41}$.

No hospício de Porto Alegre, o tratamento moral constituía-se em um dos vértices do chamado 'ecletismo terapêutico' — junto com o tratamento físicohigiênico-, que vigorou por cerca de 30 anos desde sua fundação ${ }^{42}$. O primeiro diretor, Dr. Lisboa, afirmava que ambos os métodos de tratamento eram bons, porém, estava convencido que cada um isoladamente quase nada fazia em proveito do alienado e que era, somente, «com o concurso de ambos que se tem conseguido os brilhantes resultados, que as estatísticas registram ${ }^{43}$. Porém, ainda que alardeasse os princípios do ecletismo terapêutico, $o$

39 «Atestado de admissão definitiva» - Gabinete do serviço clinico do Hospício São Pedro (1909). Em HOSPÍCIO SÃO PEDRO (1909).

40 «Relatório médico-legal dos Drs. João Pitta Pinheiro e Antonio Carlos Penafiel» (1911).

41 «Relatório médico-legal dos Drs. João Pitta Pinheiro e Antonio Carlos Penafiel» (1911).

42 Sobre as práticas terapêuticas desenvolvidas no Hospício São Pedro, cf. WADI (2002a).

43 RDHSP (1884), p. 8. Segundo Birman, a psiquiatria no século XIX destacava três grandes formas de tratamento as quais deveriam submeter-se os alienados, plenamente aceitas pelo conjunto dos psiquiatras: o físico, o higiênico e o moral. Para o autor, mesmo que esta esquematização pedagógica das formas de tratamento da alienação mental ocupasse um espaço na representação dos psiquiatras, ela se constituía numa mera enumeração e classificação dos meios curativos, sem fundamentação de sua ação especifica sobre a doença mental. Além disso, o físico e o higiênico convergiriam, enquanto instrumentos terapêuticos, para o grande núcleo de significação moral que aparece como a ação terapêutica básica da alienação mental. Cf. Birman, J. (1978), A psiquiatria como discurso da moralidade, Rio de Janeiro, Graal, pp. 
Dr. Lisbôa — como a quase unanimidade de seus colegas alienistas à épocaacreditava na supremacia do tratamento moral.

Segundo Birman, o tratamento moral era formulado como um conjunto de medidas morais, que atuavam diretamente sobre o espírito do alienado, primariamente sobre sua produção mental ${ }^{44}$. Neste sentido, o Dr. Lisbôa anunciava que «o trabalho para os alienados, a convivência com os seus companheiros, ou o isolamento quando necessário, a liberdade de que gozam, a leitura, o estudo, os jogos, os passeios, as diversas distrações, etc.» - meios de tratamento moral-, constituíam-se em «agentes de uma influencia incalculável», quer se tivesse em vista o tratamento coletivo ou o individual ${ }^{45}$. No entanto, para penetrar e agir no interior do alienado, fazendo-o cumprir princípios que identificava como elementares para a cura, o médico precisava primeiro conquistar sua confiança.

Conquistar a confiança de Pierina para fazê-la cumprir as tarefas cotidianas ou se submeter as terapias indicadas, não parece ter sido difícil para os médicos, pois não há menção a alguma rebeldia da interna no parecer médicolegal ou no prontuário e, trechos de algumas das cartas que escreveu, indicam exatamente o contrário. Ou seja, uma 'adaptação' ou 'acomodação' a rotina asilar. Certamente esta 'adaptação' teve significados vários, como lentamente se perceberá na seqüência deste texto.

A distribuição do tempo dos internos dentro do hospício era um dos princípios fundamentais da teoria e da prática médica de então, pois a instituição não podia ser um lugar de ócio na medida em que o isolamento do louco da sociedade não visava uma simples exclusão de suas fronteiras, mas a possibilidade de sua reinserção na sociedade depois de sua cura pelo tratamento psiquiátrico ${ }^{46}$. Na distribuição do tempo, o trabalho ocupava o lugar preferencial, pois, era considerado um dos principais elementos do tratamento moral.

Na percepção dos alienistas se a ociosidade no homem saudável de espírito já significava um grande mal, no alienado ela assumiria «as proporções de um verdadeiro perigo». Assim, o trabalho, ao distrair o louco dos 'devaneios' de

350-5. Ver também: CostA, J.F. (1980), História da psiquiatria no Brasil: um corte ideológico, Rio de Janeiro, Campus. As análises de MACHADO et al. (1978) e Engel (1995), sobre o Hospício de Dom Pedro II no Rio de Janeiro, ou de CunHa (1986), sobre o Hospício do Juquery em São Paulo, demonstraram a existência deste ecletismo terapêutico nos primórdios do alienismo brasileiro, cuja tônica passou a ser dada lentamente, por idéias organicistas e eugênicas (higiene mental).

44 BIRMAN (1978), pp. 350-5.

45 RDHSP (1884), p. 8.

46 MACHADO et al. (1978), pp. 439-440. 
sua loucura, prendendo sua atenção na tarefa que executava e ao mesmo tempo canalizando energias que normalmente conduziriam a excitabilidade nervosa, predispunha o corpo ao repouso, garantia de certa tranqüilidade. Por outro lado, estabelecia regras as quais o alienado pouco a pouco se adequava, numa seqüência ordenada e coordenada de passos e procedimentos, que funcionariam como uma fonte poderosa de eliminação da desordem. Não sendo nenhuma desordeira contumaz - como bem o demonstrava sua história pregressa inquirida pelos legistas - e acostumada a uma dura rotina de trabalho - como indicou nas cartas lidas pelos legistas-, certamente não foi difícil, para os médicos, enquadrar Pierina em alguma atividade 'terapêutica' de trabalho.

Da fundação até 1909, quando Pierina foi internada no São Pedro, segundo sucessivos diretores, houve poucas mudanças no tocante ao estabelecimento do chamado tratamento através do trabalho, justificadas pela ausência de oficinas destinadas a isto. Ao final do primeiro ano de funcionamento do hospício, o Dr. Lisbôa indicava que o trabalho como terapia se limitava neste a ocupação de alguns doentes na chácara do hospital como «bons auxiliares do jardineiro-hortelão», trabalhando «com verdadeiro prazer». Os demais não tinham propriamente uma ocupação, a exceção de alguns encarregados da limpeza do Hospício e de seu serviço doméstico, e de algumas alienadas responsáveis por lavar e coser as roupas do estabelecimento ${ }^{47}$. Dez anos depois, em 1894, o diretor Dias de Castro reclamava que a implementação das oficinas de trabalho - «poderoso recurso para a cura dos alienados ou pelo menos para melhorar sensivelmente as suas desordens mentais»-, ainda se encontrava em estado rudimentar. Em função do edifício encontrar-se incompleto, todas as oficinas necessárias não haviam sido criadas e, à exceção da oficina de costuras freqüentada por oito a dez mulheres — num contingente de 101 internas-, o único trabalho feito pelos enfermos consistia no serviço de limpeza do hospício — realizado pela manhã por um número limitado de alienados- e no serviço da chácara, «muito incompleto, sem divisões sistemáticas, sem recintos murados, e sem outras disposições exigidas pela casa» ${ }^{48}$.

Ainda que os alienistas centrassem a importância da terapia do trabalho no seu poder de cura da alienação mental, o benefício econômico trazido por esta não podia ser desprezado e, na realidade, constituía-se como de extrema importância para minorar problemas relativos ao próprio custeio do Hospício São Pedro ${ }^{49}$.

47 RDHSP (1884), p. 8.

48 RDHSP (1894a), p. 113.

49 Isto é visível no relatório do administrador Sr. João Evaristo da Costa, em 1894: «Na oficina de costuras, freqüentada por 8 a 10 alienadas, foram manufaturadas nesse ano 2360 
Nas primeiras décadas do século XX, a realidade em termos da terapêutica médica, não havia mudado muito. Em 1908, o Dr. Ferreira indicara em seu relatório, que este deixara de ser minucioso sobre as condições e necessidades do Hospício, pois os problemas eram os mesmos e, em breve, apresentaria ao governo do Estado um plano de reformas do hospício ${ }^{50}$. Os relatórios do período em que Pierina esteve internada na instituição até meados da década de 1920, também não são minuciosos quanto às terapêuticas aplicadas aos internos. É a leitura dos relatórios dos primeiros diretores, doutores Lisbôa e Dias de Castro, bem como relatórios do Dr. Jacintho Godoy (diretor do São Pedro a partir de 1926), que comparativamente — pelas indicações de suas crenças, das conquistas no interior do hospital e de suas queixas, quanto ao que não era implementado_, permite 'imaginar' o que se passou na época em que Pierina esteve por lá.

Como tantas outras mulheres de seu tempo, Pierina era acostumada a lavar toda a roupa da família, cozinhar, trabalhar na roça, costurar e trançar palha para fazer chapéus ou tapetes - tarefas tradicionalmente femininas na colônia italiana de onde era originária-, como escreveu em uma de suas cartas ${ }^{51}$. As habilidades com as mãos — não inatas ou comuns a natureza feminina, mas

peças de roupa para uso dos enfermos indigentes deste hospício, sendo 179 calças, 141 camisas de homem, 47 camisolas, 191 vestidos, 82 casaquinhos, 115 ditos de baeta azul, 257 camisas de mulher, 71 saias de baeta, 12 camisolas de baeta, 31 blusas de baeta, 141 saias de algodão, 10 toalhas de mesa, 66 blusas de algodão mescla, 288 fronhas, 601 lençóis e 108 ceroulas. Estabelecendo um preço mínimo por esse trabalho, podemos avaliar a sua importância em $473 \$ 800$ réis, quantia que se deve lançar à conta das economias feitas no custeio deste estabelecimento. Por aí se consegue calcular o resultado, que se chegará a obter, debaixo do ponto de vista econômico, com a organização de novas oficinas, onde aproveitando a aptidão apresentada por muitos dos enfermos aqui existentes, poderíamos confeccionar o calçado, colchões, utensílios de folha de flandres e outros objetos próprios para diversos misteres e cuja compra anual sobrecarrega a manutenção do hospício pelo Estado. A chácara do hospício, compreendendo horta e pomar, fornece com abundância frutas e verduras, consumidas na alimentação dos enfermos, e convenientemente cultivado poderia mesmo constituir mais uma fonte de receita para auxiliar o custeio do estabelecimento. Havendo para esse ramo de serviço aproveitável aptidão em grande número dos alienados, aqui asilados, e dispondo por conseguinte do trabalho braçal, elemento essencial para a cultura do solo em nosso meio, é de lamentar que a falta de recintos convenientemente murados, de modo a impedir a fuga dos doentes, embarace a execução do que eu desejara pôr em pratica». HOSPÍCIO SÃO PEDRO (1894b). Exposição referente a administração econômica, apresentada ao diretor Dr. Francisco de Paula Dias de Castro por João Evaristo da Costa, Administrador. Porto Alegre, pp. 135-6.

50 RDHSP (1908), p. 204.

51 «Carta aos dottores». HOSPÍCIO SÃO PEDRO (1909). 
forjadas em anos de aprendizado-, das quais dispunha Pierina, possivelmente fizeram com que para ela fosse indicada a 'terapêutica' oficina de costuras, em primeiro lugar. Não se têm números sobre quantas internas trabalhavam na dita oficina naquela época, mas, certamente acompanhando o número de internas que chegara a cento e noventa e oito, em dezembro de 1909, também aumentara o número daquelas que freqüentavam a oficina ${ }^{52}$. Os números da sua produção apontam para tanto, pois cerca de quatro mil peças foram 'manufaturadas' com as fazendas entradas na oficina de costuras, em 1909: blusas, casacos, saias, camisas, calças, ceroulas, coadores para café, aventais, capas de colchão e travesseiro, fronhas e lençóis, toalhas de mesa e para a farmácia ${ }^{53}$. Algumas destas peças, possivelmente, contaram com as mãos de Pierina para sua confecção.

Porém, independente da 'habilidade' manual que podiam ter algumas internas como Pierina - pois segundo o regulamento «os enfermos só se empregarão em trabalhos para que mostrarem aptidão, segundo as prescrições dos médicos» ${ }^{54}$ - na 'laborterapia' prescrita pelos médicos do hospício de Porto Alegre - por seus colegas do Rio de Janeiro, de São Paulo ou de outros lugares mais distantes-, no fundo, o que se revela é o «reforço de certos papéis e estereótipos sociais garantidores da dominação de gênero e da dominação de classe», o que significava atribuir papéis a diferentes mulheres e homens e exigir deles que, silenciosamente, os cumprissem ${ }^{55}$.

Também, não é de se duvidar, que Pierina - como outros tantos internos - tenha desempenhado tarefas que não as descritas pelos diretores, provavelmente, sem o conhecimento destes e a mando de algum empregado do hospício. Duas 'pistas' pinçadas da documentação permitem imaginar que isto possa ter ocorrido. O primeiro sinal vem na forma de um curioso artigo

52 RDHSP (1910), s.p.

53 RDHSP (1910), s.p.

54 Cf. artigo 25, RHSP (1903), p. 132.

55 CUNHA (1989), pp. 140-2. Neste sentido, afirma ainda a autora, referindo-se as prescrições que atingiam as mulheres: «Se as mulheres de 'boas famílias' não trabalham, exceto por vontade própria (para as classes dominantes, aparentemente, o trabalho não tinha qualquer valor 'terapêutico'), às mulheres das classes populares estavam reservadas tarefas condizentes com a condição feminina 'sadia'. Não importa que a interna seja uma operária fabril, uma trabalhadora do campo, uma comerciaria, uma vendedora ambulante, uma prostituta: o hospício as iguala todas nas atividades do fogão, da agulha, do bordado, para controlar seus instintos perversos e suas condutas desviantes, impondo-lhes pedagogicamente o caminho da normalidade feminina. Imitando um 'lar' coletivo, símbolo de ordem e saúde, a psiquiatria do período confere à 'cura' da loucura das mulheres a conotação imediata da domesticação». 
que consta no Regulamento do Hospital São Pedro de 1925, proibindo o que deveria ser uma prática costumeira no interior do mesmo: "Art. $110^{\circ}$ - A nenhum funcionário cabe ter doentes para serviços particulares» ${ }^{56}$. Um outro sinal mais sutil é a menção de Pierina, em uma de suas cartas, de que se dava «muito com as empregadas» ${ }^{57}$, talvez porque desempenhasse tarefas que a estas cabiam. Isto não é evidência de nada, mas certamente, não deixa de aguçar os sentidos e a imaginação histórica.

Em função da falta de dormitórios, da falta de espaço para a instalação de oficinas, da construção incompleta, da desorganização no envio de alienados para o hospício, o tratamento moral foi descrito pelos sucessivos médicos diretores do São Pedro — de Carlos Lisboa a Jacintho Godoy-, como um fracasso relativo. Porém, sem dúvida, não foi somente a esta 'parte' do tratamento médico, que Pierina, como outros tantos internos, foi submetida.

Impossibilitado de adotar o ecletismo terapêutico aconselhado pela moderna psiquiatria, tratamento que acreditava ser o «único eficaz no tratamento das psicoses», o Dr. Dias de Castro — anos antes de Pierina passar pelo São Pedro- lamentava ter de lançar mão «quase exclusivamente dos agentes físicos e mais largamente do tratamento farmacêutico, que nesta especialidade tem uma aplicação muito restrita». Além disto, o tratamento restringia-se, segundo ele, apenas às intervenções cirúrgicas reclamadas pelas moléstias somáticas e — «adotando o que a observação e a pratica têm demonstrado como mais eficaz no tratamento médico das moléstias mentais»-, ao uso «dos calmantes, excitantes, analgésicos e outros medicamentos, capazes de direta ou indiretamente exercer uma modificação favorável nas desordens funcionais do cérebro» ${ }^{58}$.

Pode-se perceber quais medicamentos eram utilizados através dos prontuários, como o da paciente Mariana, internada no Hospício São Pedro pela primeira vez em 1901 e reinternada inúmeras vezes, até seu falecimento em 1938. No tratamento de Mariana - entre 1928 e 1938 - foram utilizados remédios semelhantes aos utilizados na época da fundação do hospital, como a 'limonada purgativa', sene, magnésia fluoretada, óleo de rícino, 'água nigeia', entre outros ${ }^{59}$.

56 RHSP (1925), p. 590.

57 «Carta aos dottores». HOSPÍCIO SÃO PEDRO (1909).

58 RDHSP (1894a), p. 114.

59 HOSPÍCIO SÃO PEDRO (1901). Prontuário n. 43.765 - M. C. O. APRS (Cx. 04). O Dr. Lisboa listou os medicamentos comumente usados no São Pedro em 1884: «(...) nos casos em que o superfuncionalismo do sistema nervoso se manifesta trazendo como conseqüência 
Também para suprir a deficiência do tratamento moral recorria-se a outro «poderoso recurso»: um serviço hidroterápico. Meio terapêutico em que os médicos depositavam muita confiança funcionava, porém, de forma provisória ainda no início da década de $1920^{60}$. A instalação definitiva do gabinete hidroterápico e a instalação de um gabinete eletroterápico —onde se encontrassem «(...) aparelhos elétricos necessários para a aplicação das correntes continuas e intermitentes, para cauterizações etc.»- era uma reivindicação constante dos diretores em seus relatórios ao Governo do Estado ${ }^{61}$.

Submetida ao tratamento moral e ao tratamento higiênico ${ }^{62}$ sem dúvida Pierina o foi, como demonstra o registro feito pelos médicos legistas em seu parecer. Neste afirmavam que o repouso, o afastamento do meio familiar, o tratamento médico — sobretudo moral (psicoterapia) —, a mudança de ar e de alimentação, os melhores cuidados higiênicos fizeram com que em pouco tempo Pierina melhorasse. Assim, ela «engordou, adquiriu logo bem estar com o aproveitamento físico e moral, passando de todo o seu estado depressi-

uma excitabilidade exagerada, tenho empregado: o bromureto de potássio, o bromureto de sódio, o cloral, a beladona, o meimendro, o ópio, a morfina, etc. Lanço mão também nos casos, a que me refiro, dos banhos frios, e deles raramente tenho deixado de tirar reais vantagens. Quando o alienado apresenta justamente o estado oposto, ao que venho falar, isto é, quando a depressão domina a cena, lanço mão da noz-vômica, da valeriana, dos tônicos, e quando este estado depende ou se acha ligado à anemia, à clorose ou a ambas estas moléstias reunidas, emprego os ferruginosos e as preparações iodadas, etc. O iodureto de potássio, o sulfato de quinina, a digitalis, os eméticos, os purgativos, os emenagogos, os revulsivos, etc., são ainda medicamentos, de que tenho lançado mão conforme as indicações se apresentam». RDHSP (1884), p. 9.

60 O anexo preparado para receber o serviço hidroterápico constava «(...) de uma larga piscina de alvenaria para banhos de imersão (...) com proporções para permitir aos enfermos franca liberdade em seus movimentos e construída ao nível do solo, do qual é separado por um reborbo (...). Alimentada por uma torneira de grande diâmetro, colocada fora do alcance dos alienados, ele oferece grande facilidade para a renovação da água que pode ser prontamente esgotada por uma saída subterrânea. Além dessa piscina a sala de hidroterapia dispõe ainda de dois aparelhos para duchas cervicais simples e de duas torneiras, ás quais se pode adaptar duchas em lança, duchas em lamina e duchas campanuladas, e é completada com um quarto contíguo, onde se acham colocadas três banheiras para banhos mornos simples ou com afusões frias na cabeça». RDHSP (1894a), pp. 114-115.

61 RDHSP (1884), p. 10.

62 Segundo Birman, o tratamento higiênico correspondia à realização e disposição de um conjunto de medidas gerais, sem especificidade do ponto de vista etiológico, como exercícios, formas de alimentação, vestimentas, locais fisicamente adequados para dispor o paciente, aquecimento do ambiente, etc. Cf. BIRMAN (1978). 
vo cerebral e, com este, as idéias anormais que a acompanhavam como parasitas do pensamento ${ }^{63}$.

Por outro lado, nada registrado nas cartas, nada no prontuário, nada além do sinal tênue deixado pelo parecer médico-legal — «aproveitamento físico»-, permite saber com exatidão, se Pierina foi submetida ao chamado tratamento físico, ou seja, aquele que utilizava meios - como as duchas, os banhos de imersão, as sangrias, os purgativos, os medicamentos...- «que atuassem diretamente sobre o corpo doente do alienado» ${ }^{64}$.

Segundo Cunha, muitas das práticas que constituíam o chamado tratamento físico não passavam de práticas de tortura com status de remédio, mesmo que, inúmeras vezes, não se tivesse idéia do próprio efeito terapêutico de tais práticas para os internos ${ }^{65}$. Os banhos, por exemplo, eram dados frios ou quentes ou de forma alternada-, em banheiras de imersão ou através de «duchas em lança, duchas em lamina, duchas campanuladas» - como previa o Dr. Dias de Castro66 - ou ainda, em duchas circulares, «aposentadas por causarem freqüentemente mortes por afogamento nos internos» ${ }^{67}$. Simultaneamente aos banhos quentes, podiam ser aplicados, 'capacetes de gelo' na cabeça. O terror gerado por tais terapias inspirou muitas queixas registradas em cartas, bilhetes, muros e paredes dos hospícios pelos pacientes e, nos prontuários, pelos médicos. Nestes últimos registros, comumente, as queixas foram interpretadas como 'resistências' aos tratamentos propostos ou a própria situação de internação ${ }^{68}$.

Nada semelhante, no entanto, foi registrado por Pierina. Nenhuma queixa. Ao contrário, de uma resistência inicial a internação manifesta em uma de suas $\operatorname{cartas}^{69}$ ou a imagem 'infernal' do São Pedro que pintou em outra, logo

63 «Relatório médico-legal dos Drs. João Pitta Pinheiro e Antonio Carlos Penafiel» (1911).

64 BiRMAN (1978), pp. 350-5.

65 CunHA (1986), p. 98.

66 RDHSP (1894a), pp. 114-115.

67 RDHSP (1894a), pp. 114-115.

68 Segundo Cunha, «uma surda prática de resistência se instala no âmago da vida asilar e seus sinais dispersos e fugazes - mas não totalmente apagados - contaminam os registros da própria vida do hospício. 'Cago nas suas artes de curar (...) eu fico com a minha loucura', escreve um paciente, indignado com a disciplina asilar à qual era forçado a submeter-se — tratava-se mesmo de um contumaz freqüentador das 'rotundas'. Os relatos de visitas e reportagens da imprensa sobre o Juquery - aliás bastante freqüentes no primeiros anos, quando podia ainda ser considerado modelar - estão repletos de episódios de resistência e denúncias dramáticas, certamente nunca levadas muito a sério, posto que partidas de indivíduos desqualificados, os loucos». CunHa (1986), pp. 101-2.

69 «Carta ao Juiz de Garibaldi». HOSPÍCIO SÃO PEDRO (1909). 
quando admitida no hospital, não parece ter sobrado nada com o passar do tempo. Ao que parece, em pouco tempo, sobreveio uma imagem positiva da instituição cuja simples menção lhe causara calafrios anteriormente: «eu para sair daqui, ficaria, muito sentida $\rangle^{70}$. Elogios ao tratamento que lhe era dispensado no hospício, também foram registrados na carta que escreveu para sua mãe em 08 de outubro de 1909, apenas quatro meses depois de internada: «Minha querida Mãe. Eu vou, indo, muito bem, bem tratada, e respeitada de todos, que nem mereço» ${ }^{71}$.

É impossível saber o quê, de fato, fez com que mudassem as impressões de Pierina sobre sua internação no hospício. Teria sido a rotina e disciplina asilar que cercava por todos os lados, dia e noite, os internos com «atividades tendentes a 'revigorar' sua moral e bons costumes»? ${ }^{72} \mathrm{Ou}$ foram as terapêuticas destinadas a quebrar resistências e rebeldias de todos os tipos, que mudaram a percepção de Pierina? É de fato, bastante provável, que isto tenha acontecido, pois, como afirmou Castel, apesar do tratamento moral constituir-se como uma imagem discutível, a sua adoção pela psiquiatria nascente — juntamente com os complementares tratamentos físico e higiênico- é bastante esclarecedora da poderosa fonte de geração de poder que constitui seu âmago ${ }^{73}$.

A comprovação da eficácia terapêutica do hospício, segundo Cunha, foi dada pelas imagens - ou provas ambulantes - dos internos que exibiram «a marca do asilo em seu rosto e postura corporal: olhos baixos, ombros curvados, atitude humilde, mansidão $\rangle^{74}$. Não se têm como saber se Pierina ficou assim, pois não há fotografias anexas ao prontuário. Sabe-se apenas que, a despeito da dura rotina asilar a qual ela como tantos outros internos em hospitais psiquiátricos do início do século XX, certamente foi submetida - buscando incitar a «normalidade de sua afetividade», a fazer com que afastasse «as idéias anormais que a acompanhavam como parasitas do pensamento» ${ }^{75}$ - , Pierina pas-

\footnotetext{
70 «Carta aos dottores». HOSPÍCIO SÃO PEDRO (1909).

71 «Carta de Pierina à mãe». HOSPÍCIO SÃO PEDRO (1909).

72 Cunha (1986), p. 97.

73 Segundo Castel: «(...) o tratamento moral forma uma espécie de triângulo disciplinar que coloca em relação o médico, o doente e a instituição. É a relação hierárquica e regulada entre esses três pólos que constitui seu dinamismo e explica a eficácia que se lhe atribui. Um sujeito todopoderoso impõe sua vontade racional a um sujeito completamente desmunido, por intermédio de suportes institucionais agenciados para repercutir e multiplicar este poder: pessoal subalterno, regulamentos, emprego do tempo, atividades reguladas, etc.». CASTEL (1978), p. 261.

74 CunHa (1986), p. 97.

75 «Relatório médico-legal dos Drs. João Pitta Pinheiro e Antonio Carlos Penafiel» (1911).
} 
sou a ver no São Pedro, paradoxalmente, uma possibilidade de encontrar um lugar para si. Não pela aceitação da condição de 'louca', que ela negava, mas como 'empregada'. Esta tentativa ficou demarcada quando, encerrando sua carta aos doutores, Pierina afirmou não ter doença nenhuma, poder trabalhar dia e noite, ter uma boa memória — «que desde a idade de cinco anos, sei lhe contar a minha vida»-, aprender rapidamente qualquer trabalho e assim solicitou: «Se os senhores me desse um empreguinho aqui, no hospício, de ganhar um 15 mil réis, por mês, pra mim chegaria (...)» ${ }^{76}$.

Mas o que fez com que Pierina tivesse a idéia de trabalhar no hospício ganhando uns trocados para se manter? Pode ter contribuído para isto, o que parece contraditório a primeira vista, manifestações esboçadas por pessoas que conviveram com ela no hospício. Segundo relatou em sua carta dirigida ao Juiz do Crime, tanto o Administrador, quanto enfermeiros, empregados, o padre e o próprio médico responsável por seu tratamento não achavam que ela era alienada e que, portanto, o hospício não era um lugar para ela: «as enfermeira, e os enfermeiro me disse que aqui eu não fosso ficar e o Doutor, eles me disse aqui e lugar dos locos e locas mas não das criminosas (...) hoje o Ministrado me disse não chora que [sic] o chefe não vem te busca tu vai na Rua aqui tu não pode ficar» ${ }^{77}$.

Certamente, as razões de tais posturas foram as mais diversas. Para o médico, certamente estava em jogo nesta época — no recebimento de uma mulher que matara a filha no São Pedro-, a discussão sobre a necessidade de se construir seções ou estabelecimentos especiais destinados a receber indivíduos situados na fronteira entre a razão e a loucura, por terem cometido crimes que subvertiam escandalosamente valores básicos que se pretendia enraizados na própria natureza humana, como o amor materno. Entretanto, ainda que motivadas por razões diferentes — talvez até pela 'pena' que sentiram de uma mulher, que além de ter cometido um crime infame como matar a própria filha, ainda estava condenada a viver no 'inferno' que era o hospício-, as posturas descritas por Pierina, foram por ela mobilizadas no sentido de reservar-lhe um lugar diferente na instituição: não como uma 'interna louca', mas como uma 'saudável empregada'.

Pierina certamente soube, ao adentrar o hospício, que as religiosas da Congregação de São José - a mesma congregação que administrava o colégio em Garibaldi no qual estudara - responsáveis pela enfermagem da seção feminina, preferiam ter internas como ajudantes. Segundo o Dr. Godoy, «di-

76 «Carta aos dottores». HOSPÍCIO SÃO PEDRO (1909).

77 «Carta ao Juiz de Garibaldi». HOSPÍCIO SÃO PEDRO (1909). 
tas religiosas, com exceção de uma ou outra, não tinham tirocínio hospitalar, menos ainda de enfermagem especializada» e preferiam ser auxiliadas pelas «próprias doentes» ${ }^{78}$. Pierina pode ter acreditado na possibilidade de se tornar uma das ajudantes das irmãs, pois afinal, fora com algumas delas que aprendera muito do que sabia.

Por outro lado, o contato entre empregados e internos 'produtivos' era intenso, pois aos primeiros cabia dirigir ou, segundo o regulamento em vigor, 'entreter' os alienados, em suas ocupações de trabalho ${ }^{79}$. Era o jardineirohortelão — guardião dos instrumentos e utensílios de lavoura - que deveria dirigir «os alienados que, por ordem do médico, forem destinados para o serviço da horta, não podendo, porém, obrigar ao trabalho aquele que a isso se recusar» ${ }^{80}$. Já as internas, que 'ajudavam' no serviço de lavagem das roupas do hospício, eram orientadas pela lavadeira Felisberta Gomes Pinto que fora contratada apenas três meses depois de Pierina ter entrado no hospital, permanecendo na função por quase dezesseis anos ${ }^{81}$. Desse contato diário - na horta, na lavanderia, na cozinha ou na oficina de costuras- com empregados e empregadas, pode ter surgido outro incentivo à crença de Pierina de que poderia passar da condição de interna para a de 'empregada' no hospício: em seu envolvimento nas atividades rotineiras, ditas 'domésticas' e consideradas como parte do 'tratamento moral', Pierina estabeleceu algumas relações de amizade ou solidariedade, com outras mulheres que trabalhavam duro - tão duro como ela sempre trabalhara-, e que, com certeza, no dia-a-dia, compartilhavam com ela algumas de suas mazelas, bem como alguns de seus sonhos.

As mulheres e os homens que exerciam funções diversas no São Pedro eram gentes tão ou mais pobres do que Pierina e a maioria dos internos. Talvez muitos deles compartilhassem com ela, além da situação de classe ou

78 Godoy (1955), pp. 161-2. A presença exclusiva de freiras e internas na seção feminina, inaugurada em 1910, teria perdurado pelo menos até os anos 20, segundo o diretor, época na qual, com a instalação de novos «banheiros terapêuticos, em série» e a organização de «salas de clinoterapia para doentes com vigilância contínua», foi necessária a admissão de novas auxiliares femininas «leigas, antigas funcionárias».

79 Cf. «Art. 24 - Fora das horas de descanso, os enfermos serão entretidos em ocupações de trabalho, instrução e recreio (...)». RHSP (1903), p. 132.

80 Cf. artigo 42, RHSP (1903), p. 139.

81 Através de um ato governamental, a lavadeira do HSP, Felisberta Gomes Pinto, após 15 anos, 10 meses e 7 dias de trabalho, foi aposentada do serviço efetivo «no qual adquiriu invalidez permanente e total». RIO GRANDE DO SUL (1925). Ato $\mathrm{n}^{\circ} 371$, de 17 de julho de 1925. Aposenta do serviço efetivo do Hospício São Pedro a lavadeira Felisberta Gomes Pinto, Porto Alegre, AHRS (CL 680). 
gênero, uma mesma origem étnica e uma mesma lógica cultural. Possivelmente foi também, no contato travado com essas gentes que compunham o contingente de empregados da instituição, que Pierina tomou conhecimento quanto aos valores recebidos por eles a guisa de salário. Possivelmente, tal conhecimento lhe permitiu sugerir aos doutores o que ela como empregada poderia ganhar ${ }^{82}$. Os salários pagos na época ao pessoal do hospício eram, segundo o Dr. Dias de Castro, inferiores ao de qualquer jornaleiro ${ }^{83}$, entretanto, Pierina tentou convencer os doutores, pedindo humildemente que lhe dessem «por favor», tendo dela «piedade», um «empreguinho (...) no hospício», ganhando «uns 15 mil réis, por mês», bem menos do que os empregados ${ }^{84}$.

Contrariando as primeiras imagens de rebeldia e horror esboçadas - não era louca, o hospício era um inferno, não agüentava e nem podia dormir com os gritos que os loucos davam, a comida do hospício nem os cachorros podiam comer...-, em sua carta 'aos doutores', que parece ter sido uma das últimas que escreveu no hospício, Pierina disse estar se «acostumando», ser «muito bem tratada» e que de lá «não sairia contente», apesar das saudades que sentia da família e do arrependimento de seu crime. Tanto que pediu aos médicos que lhe dessem o tal «empreguinho» ${ }^{85}$.

Esta mudança no comportamento, esboçada em algumas de suas cartas, aparentemente poucos meses depois do internamento — mas após já estar 'integrada' a rotina asilar com sua disciplina e suas práticas terapêuticas-, fez com que os médicos legistas, bem como o médico adjunto do hospício, acreditassem estar Pierina curada. Vivendo no mundo do hospício, que pre-

82 Não se tem dados sobre os anos 1909 a 1911, mas os dados de alguns anos antes e de alguns depois, permitem imaginar a quanto andava os vencimentos do pessoal do hospício naquela época. Em 1889, por exemplo, os primeiros enfermeiros - homens e mulheresganhavam $40 \$ 000$ (quarenta mil réis) mensais cada um, seus ajudantes $30 \$ 000$, uma lavadeira $30 \$ 000$, um porteiro $25 \$ 000$, um cozinheiro $40 \$ 000$ e seu ajudante $30 \$ 000$. Já em 1913, os salários estavam mais altos e vamos encontrar o enfermeiro-mor ganhando $150 \$ 000$, os demais enfermeiros $100 \$ 000$, a $1^{\text {a }}$ enfermeira religiosa (ou enfermeira-mor) ganhando $60 \$ 000$, suas ajudantes religiosas recebendo $30 \$ 000$ cada uma, uma lavadeira 55\$000, o porteiro $50 \$ 000$, o cozinheiro $110 \$ 000$ e seu ajudante de cozinha 55\$000, enquanto a costureira religiosa ganhava 30\$000. Cf. RIO GRANDE DO SUL (1889). Ato $\mathrm{n}^{\circ} 34$, de 29 de dezembro de 1889. Arbitra os vencimentos do médico-diretor do Hospício São Pedro e aprova tabela do respectivo pessoal com seus vencimentos. Porto Alegre, AHRS (CL 614); RIO GRANDE DO SUL (1913). Decreto $n^{0} 1.949$ A, de 24 de março de 1913. Estabelece os vencimentos dos funcionários do Hospício São Pedro. Porto Alegre, AHRS (CL 653).

83 RDHSP (1896), p. 219.

84 «Carta aos dottores». HOSPÍCIO SÃO PEDRO (1909).

85 «Carta aos dottores». HOSPÍCIO SÃO PEDRO (1909). 
tendia corrigir os vícios do mundo real através de seu próprio espaço, Pierina, no olhar dos médicos, podia voltar a ocupar seu lugar naquele -inclusive respondendo frente à justiça por seu crime-, pois demonstrara ter recuperado sua afetividade, os sentimentos que vinha negando, seu verdadeiro papel como mulher.

Porém, partindo quase do mesmo lugar — ou seja, do seu 'acostumar' ao São Pedro-, a escrita de Pierina mostra outra dimensão que certamente contrasta profundamente com a dos médicos, ainda que possa ser confundida a primeira vista, com suas posições. No mundo do São Pedro - no outro lado do espelho, «lugar do contrário, daquilo que é simetricamente oposto, imagem invertida que confirma e subverte seu modelo» ${ }^{86}$ - , neste mundo das terapêuticas, da disciplina e da rotina médica, Pierina pode ter enxergado possibilidades novas, que não torna tão simples dizer que ela foi simplesmente dobrada ou quebrada pelas práticas psiquiátricas. Escrevendo para sua mãe Maria, em oito de outubro de 1909, desejava saber notícias de toda sua gente - especialmente da mãe e do marido-, solicitava que esta lhe enviasse toda sua roupa, cobertas, dois travesseiros bem cheios, seus cadernos, o livro de missa, retratos da mãe, dos amigos, dos compadres, do marido e das famílias dos irmãos e irmãs, além de bastante «palha branca, e de cor de numero 1,3,5, 7, 9» para fazer tapetes. Afirmava enfim: «Minha querida mãe muitas saudades de toda a minha gente, mas eu, em Garibaldi não desejo de voltar mais» ${ }^{87}$.

Sua recusa em voltar para casa, presente também na carta que escreveu aos doutores, apesar do arrependimento, das saudades da família, dos amigos e conhecidos - e a qual os médicos, ao que parece se fizeram de surdos-, revela muito. Revela coisas que ultrapassam os sentidos que a elas podem dar os operadores de diversas artes de curar, como médicos, psiquiatras ou psicólogos.

Atentando-se para os fragmentos deixados por sujeitos que, como Pierina, vivenciaram a experiência da loucura, ultrapassando-se os estreitos limites da lógica médica, e percebendo-se os contornos sociais e culturais de cada experiência, é possível perceber as questões de vida envolvidas em cada história particular. Ao olhar para uma experiência particular, contextualizada em uma situação histórica e social precisa, é possível, entrever, algo que sempre escapou a muitos psiquiatras - para os quais a loucura é totalidade fora da história, constante universal, regularidade a-histórica, para a qual sempre buscaram uma explicação final ${ }^{88}$, ou seja, que toda experiência, inclusive a da

86 CunHa (1986), p. 13.

87 «Carta de Pierina à mãe». HOSPÍCIO SÃO PEDRO (1909).

88 CUNHA (1986). 
loucura, têm «dimensões múltiplas (...), matérias e signos, elementos díspares, lógica incomum, cenas, falas, temporalidades» ${ }^{89}$.

Fecha de recepción: 16 de septiembre de 2007.

Fecha de aceptación: 11 de marzo de 2008.

89 Pelbart, P.P. (1995), Os loucos trinta anos depois, Novos Estudos CEBRAP, 42, p. 176. 